\title{
Ativismo comunitário e relações geracionais no feminismo contemporâneo norte-ame- ricano
}

\author{
Everywhere \& Nowhere: \\ Contemporary Feminism in the \\ United States. \\ REGER, Jo.
}

New York: Oxford University Press, 2012 , $256 \mathrm{p}$.

Professora de Sociologia e diretora do Programa de Estudos da Mulher e Gênero da Universidade de Oakland, Jo Reger vem se dedicando, desde a década de 1990, ao estudo do movimento feminista contemporâneo nos EUA. Interessa-se especialmente por compreender como identidades coletivas são construídas nesse movimento, tema de seu livro "Identity Work in Social Movements" (University of Minnesoto Press, 2008).

Em Everywhere \& Nowhere, a autora examina a vitalidade do movimento feminista norteamericano, mostrando como jovens ativistas de três diferentes áreas do país têm buscado construir uma identidade feminista a partir das relações de diferença e semelhança com as gerações mais velhas e das oportunidades colocadas pelo contexto político e cultural comunitário. A autora se debruça sobre organizações feministas comunitárias, contrastando-se à tradição de estudos que foca em organizações formais, de grande visibilidade nacional, atuando junto ao Estado e ao parlamento. A imagem de "ondas", muito difundida nas narrativas históricas do feminismo produzidas por essa tradição, é criticada porque toma essas organizações nacionais como porta-vozes de um movimento que é, na verdade, diversificado em escalas de atuação, modos de associação, táticas e temas. Além disso, a noção de ondas enfatiza as diferenças e rupturas entre atores e movimentos, enquanto as relações de continuidade são preteridas.

Diante disso, Reger opta pelo foco em movimentos comunitários e sua pluralidade de organização e estratégias de ação. Ela argumenta que a interação nos contextos comunitários é o que explica o modo como o feminismo segue sendo dinâmico e relevante para as gerações atuais, mesmo em momentos de menor visibilidade das grandes organizações nacionais. Ademais, o uso da noção de "gerações" procura superar as dificuldades epistemológicas das "ondas" ao permitir situar diferentes grupos de feministas simultaneamente ativos, mantendo entre si relações de cooperação e conflito, continuidade e ruptura.

A autora analisa dados produzidos em pesquisa de campo junto a três organizações feministas localizadas no Centro-Oeste, na Costa Leste e no Noroeste do país. Além de observação participante, foram realizadas entrevistas com 40 ativistas, em que se exploraram questões como definições de feminismo, narrativas sobre o processo de se tornar uma feminista, semelhanças e diferenças entre as gerações contemporâneas e mais velhas de ativistas, objetivos, táticas e networks.

Na primeira parte do livro, Reger aborda o processo de construção de identidades entre as entrevistadas. Vivendo num contexto em que a igualdade de gênero é tomada como dada "feminismo em toda parte" - sem que os rastros da transformação histórica das relações de gênero estejam aparentes, dada a ausência de grandes lideranças nacionais - "feminismo em lugar nenhum" -, as novas gerações passam por um processo gradual de se tornarem feministas. Suas variadas experiências educacionais, de sexualidade e violência, suas relações com uma geração feminista de segunda onda e as características do contexto comunitário são importantes nesse processo de formação das identidades feministas contemporâneas. Assim, das três organizações pesquisadas emergem diferentes perfis identitários.

Na segunda parte, o livro trata das ações e táticas do feminismo contemporâneo. Revelando continuidade com as gerações anteriores, as entrevistas elencam aborto, violência contra a mulher e igualdade salarial como seus principais temas. Por outro lado, a liberdade de escolha acerca de seus corpos e sexualidade é um tema muito valorizado também. Suas táticas são majoritariamente de tipo "cultural", isto é, privilegiam a mudança das normas culturais de 
gênero por meio da educação e empoderamento pessoal, e se contrastam com, embora não excluam, as táticas "institucionais", que buscam mudanças legislativas e demandas por políticas públicas.

Como resultado de um diálogo crítico com as gerações anteriores, o tema da diversidade de raça, classe e sexualidade se tornou central na definição da identidade e políitica feministas das três organizações estudadas, assim como para o feminismo contemporâneo de modo geral. Entretanto, os diferentes contextos comunitários condicionam o modo como as três organizações lidam efetivamente com a diversidade na construção de suas identidades políticas. As comunidades feministas do CentroOeste e Noroeste, com mais de $90 \%$ de ativistas brancas, são menos predispostas a abordar assuntos sobre racismo que a comunidade da Costa Leste, que tem uma composição racia mais diversa e, logo, interage numa rede de ativismo também mais diversa. Em todas as comunidades, as integrantes são, em sua maioria, da classe média. É no campo das identidades sexuais que a diversidade é mais aparente, e a maioria das integrantes se identifica ora como lésbicas ora como queer, o que, mais uma vez, depende de fatores contextuais, como a exposição aos estudos de gênero e o grau de aceitação ou hostilidade enfrentado.

Embora avalie como positiva a desconstrução do sexo e do gênero pelo feminismo, para Reger, o quadro analisado mostra que o feminismo contemporâneo norte-americano pouco avançou para colocar em prática questões de raça e privilégio. Talvez aqui a autora generalize resultados de uma amostra branca e de classe média, tomada, mais uma vez, como represen- tativa do movimento em sua totalidade. Principalmente, a própria linguagem das identidades políticas tem em si uma dinâmica interna própria que torna mais complexa a questão da diversidade no feminismo. A constituição de sujeitos políticos em torno de identidades sexualizadas, generificadas, racializadas e de classe não é apenas reflexo das desigualdades objetivas dos contextos comunitários, mas também resultados de disputas por reconhecimento e poder no interior do movimento feminista, que mobilizam interesses de todas as forças, inclusive, e especialmente, as "subalternas".

O livro traz um vibrante e acurado retrato do feminismo contemporâneo dos EUA, relacionando de modo habilidoso dados empíricos e insights teóricos. No campo dos estudos sobre movimentos sociais, o estudo é relevante pelo foco nas interações comunitárias que dão sentido e continuidade ao ativismo e que não são detectáveis a nível nacional. Para os estudos de gênero a discussão sobre como as diferentes gerações de feminismos se relacionam e produzem identidades específicas é de inestimável valor.

Protestos como a Marcha das Vadias e o Femen, campanhas virais como "Eu não mereço ser estuprada", o crescimento de coletivos de mulheres dentro de organizações políticas de esquerda e a proliferação de grupos feministas autônomos diversos no Brasil sugerem que, também aqui, o movimento feminista, apesar de inúmeras especulações sobre sua crise ou fim, permanece vigoroso. O livro de Jo Reger permite imaginar diálogos que falam sobre processos de continuidade e mudança no feminismo, que embora ancorados nas realidades locais, também as transcendem.

Carla de Castro Gomes Universidade Federal do Rio de Janeiro 